Available online at: https://proceeding.researchsynergypress.com/index.php/rsfconfereceseries1 RSF Conference Series: Business, Management and Social Sciences ISSN XXXX-XXXX (Online) |XXXX-XXXX (Print)

Volume 1 Number 2 (2021): 01-09

\title{
Investment Project of Sekala: Should Sekala Open Up a New Outlet?
}

\author{
Fario Pranadi Prakoso1, Sylviana Maya Damayanti² \\ ${ }^{1}$ Postgraduate Student of School of Business and Management, Institut Teknologi Bandung, Indonesia \\ ${ }^{2}$ Lecturer of School of Business and Management, Institut Teknologi Bandung, Indonesia
}

\begin{abstract}
Coffee is one of the most consumed beverages in the world, coffee consumption in the world and Indonesia is growing rapidly year to year. Even in the pandemic, the demand for coffee is still high. This was the reason that there are so many new coffee shops, but some of them did not last long, the main reason was they are not preparing the calculation precisely. Sekala was planning to open up a new outlet in Bandung, with the measurement projection using capital budgeting from the year 2022-2026. This was required to measure whether the project is feasible or not. The project will be considered feasible if it meets certain analysis that was provided by feasibility analysis, sensitivity analysis, and Monte Carlo simulation. Feasibility analysis is required to show whether the projection is feasible or not. Sensitivity analysis is used to measure some criteria that affect the most Sekala in terms of the financial side, later on, it will be used on Monte Carlo analysis to see the project feasibility based on several simulations. The initial investment for this project is IDR 242,177,275.60, and the result of this projection is, payback period of 1.22 years, an estimated NPV of IDR 513,913,208.73, benefit/cost ratio of 3.12, and an internal rate of return of $52.04 \%$. The sensitivity analysis result shows that the 4 most influential criteria are affecting the business. Monte Carlo simulation results show that this project has a high chance probability of giving $N P V<0$, for $40-55 \%$.
\end{abstract}

Keywords: Coffee, New Outlet, Feasibility Analysis, Sensitivity Analysis, Monte Carlo Simulation

\section{INTRODUCTION}

The business world keeps growing every year. Even in this pandemic, business keeps on coming in every corner of the world, and online businesses also started popping up. Culinary industries are the most vulnerable to be exploited by new entrepreneurs. New entrepreneurs only have to find the right innovation to dive into the culinary industries. In the middle of a pandemic, coffee shops, restaurants, and other businesses are getting harder to gain profits. They need to adapt to the current situation, for example, they need to follow the "New Normal" or social distancing regulation which will reduce the capacity on the spot, and they also need to maximize the use of online sales. And with the current recession, every entrepreneur needs to measure everything perfectly, so the plans are going according to what they want. This will be a big issue for the nation or any business itself, as it will reduce the buying power of customers and will keep piling up the weight for new or old businesses. Despite the economic growth declining, it did not affect every single type of business, food and beverages are the types of businesses that can still run in the middle of this pandemic if they can maximize the online sales.

According to Ann Pietrangelo in Healthline (Healthline, 2018), coffee is one of the most consumed beverages in the world right now, not only for its tastes but also for its efficacy. Coffee consists of caffeine, when caffeine reaches peoples brain, it will lead to alertness to who consume it and will make the consumer awake and feel less tired.

According to "Perfect Daily Grind" (Grant, 2020), The consumption of coffee also rapidly increasing year to year in every corner of the world, as you can see in the graph above, in fact, sales

Corresponding author

fario_pranadi@sbm-itb.ac.id; sylvianamaya@sbm-itb.ac.id

DOI: $10.31098 /$ bmss.v1i2.255

Research Synergy Foundation 
of RTD (ready-to-drink) coffee in the UK rise by $129 \%$ in the first few months of pandemic and the forecasted sales is expecting that the sales will keep increasing by the year. In Indonesia, the consumption of coffee also increasing year by year based on the data provided by statistica.com.

\section{Total coffee consumption in Indonesia from 1990 to 2019 (in 1,000 60kg bags)}

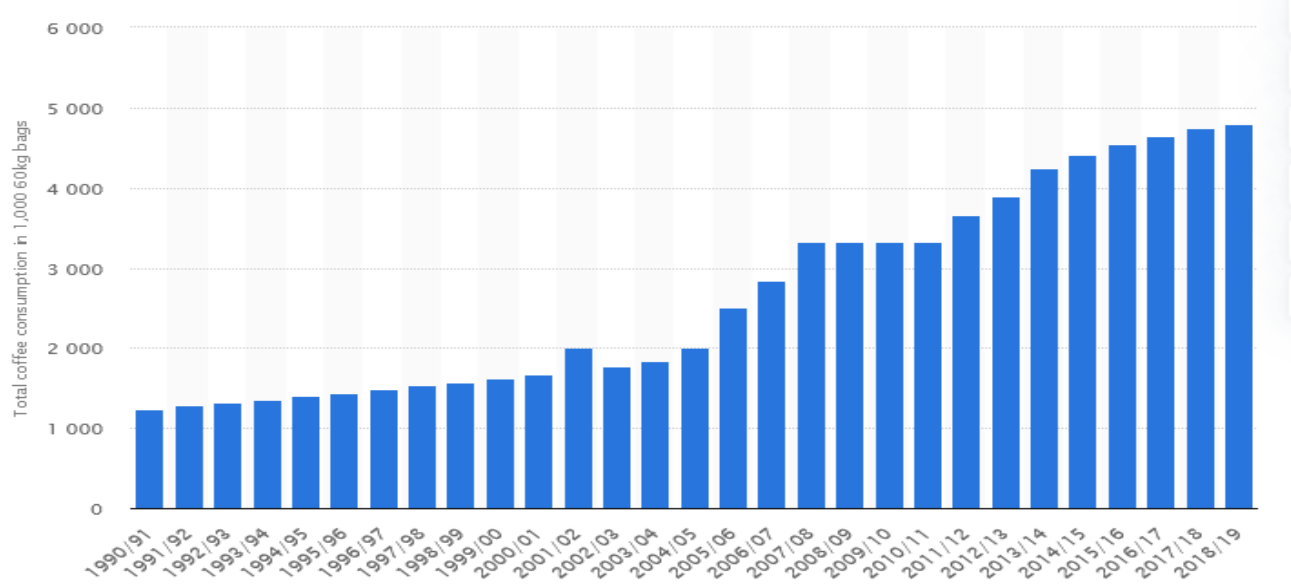

Figure 1 World Coffee Consumption

(Source: ico.org, 2021)

As we can see that new businesses are growing rapidly, but there is also some concern about how fast they went bankrupt. Entrepreneurs sometimes follow the hype or their intuition without further preparation. One of the preparations that the entrepreneurs should prepare was capital budgeting. Capital Budgeting is a method to measure how are the financial requirements for a project or investment and to show how the project or investment will result in the end. Capital budgeting can be used as a decision-making method for whether the investment should be or should not be implemented.

Research Questions:

1. What will be the outcome of the financial projection for Sekala, the Common Place new Outlet?

2. How big is the success probability for the project?

\section{LITERATURE REVIEW}

The purpose of this research was to measure the capital budgeting for Sekala, based by (Agnes Cheng \& Newman, 2014) Capital budgeting is one of a process of resource allocation that will affect the production of future sales, capital budgeting consists of 4 phases: identification, evaluation, selection, and control. Capital budgeting programs are investments that an organization must, must make, or intends to make, which may be ongoing or newly developed operations.

A survey of capital budgeting method was provided by (Ashley, Atkinson, \& LeBruto, 2013), the study was created to determine what capital budgeting method is being used by foodservice segment industry, the study finds out from the survey asset size, size of the annual capital budget, 
project size required, and percentage of project acceptance for capital budgeting of foodservice segment, the project also shows that the finding of capital budgeting technique that is frequently used by the industry.

Research for the evaluation of capital budgeting techniques provided by (Siziba 2019) examines how are the application of capital budgeting techniques in some countries, the study result shows that some capital budgeting techniques are the most popular method which is commonly used, there is the net present value (NPV), internal rate of return (IRR), payback period (PBP), accounting rate of return (ARR), return on investment (ROI), and a real optional value (ROV).

Also, research by (Hall 2000) shows what aspects of capital budgeting are is the most important to be used in the evaluation of project investment, the results show that project definition and cash flow estimation is the most important part rather than the financial analysis itself, with return on investment (ROI) and internal rate of return (IRR) are the most used method to define project feasibility.

\section{RESEARCH METHOD}

For this study, the author mostly used quantitative data and approaches to calculate the capital budgeting of Sekala's new outlet. First, the data must be collected from Sekala's management and report as the primary data that will be used until the end of the research. After all the data is collected, the author will construct the calculation based on the analysis methods chosen. The analysis methods consist of internal rate of return, net present value, payback period, the average rate of return, and benefit/cost ratio. After the calculation, the result will be the decider for Sekala's owner and management to implement or not to implement the new outlet project. The data collected is primary data received from interviews and focus group discussions with the Sekala's management and owner, and some of the other data will be collected from their financial report. The data collected will be the monthly financial summary from Sekala's monthly business operations. The capital budgeting analysis method that this research use will be based on the " $A$ Survey of Capital Budgeting Methods Used by the Restaurant Industry" article (Ashley, Atkinson, \& LeBruto, 2013), author use 4 of the most popular primary capital budgeting techniques, there is Internal Rate of Return (IRR), Net Present Value (NPV), Payback Period, and Benefit/Cost Ratio (B/C Ratio). Then the research will be continued using Sensitivity Analysis and Monte Carlo Simulation.

\section{FINDINGS AND DISCUSSION}

For this study, the initial investment of Sekala is divided into two costings, from owner equity by $30 \%$ and long-term bank loans with 5 years tenure by $70 \%$. The initial investment was $242,177,275.60$ with a $4.23 \%$ inflation average rate from $2011-2020$.

Table 1 Initial Fixed Assets Investment

\begin{tabular}{|l|c|c|c|}
\hline Assets (in IDR) & $\begin{array}{c}\text { Asset's } \\
\text { Life }\end{array}$ & Value & Markup Value (+Inflation) \\
\hline Installation & 5 & $100,000,000.00$ & \\
\hline
\end{tabular}


RSF Conference Series: Business, Management and Social Sciences, Vol. 1 (2), 01-09

Investment Project of Sekala: Should Sekala Open Up a New Outlet?

Fario Pranadi Prakoso, Sylviana Maya Damayanti

\begin{tabular}{|c|c|c|c|}
\hline & & & $104,234,000.00$ \\
\hline Bar Equipment & 5 & $110,300,000.00$ & $114,970,102.00$ \\
\hline Kitchen Equipment & 5 & $11,500,000.00$ & $11,986,910.00$ \\
\hline Dining Equipment & 2 & $3,540,000.00$ & $3,689,883.60$ \\
\hline Sound System & 5 & $3,000,000.00$ & $3,127,020.00$ \\
\hline Office Equipment & 3 & $4,000,000.00$ & $4,169,360.00$ \\
\hline Tota & & $232,340,000.00$ & $242,177,275.60$ \\
\hline
\end{tabular}

The cost of debt of this financing using the cost of debt after tax is $7.43 \%$ from the rate of 8.25\% from the average of average retail of SDBK of Bank Nasional Indonesia (BNI), Bank Central Asia (BCA), Bank Rakyat Indonesia (BRI, with 10\% tax rate for restaurant, there is additional 3.5\% provision that will be paid one time in the beginning.

Capital Assets Pricing Model (CAPM)

$R_{i}=$ Expected Return of Investment

$$
R_{i}=R_{f}+\beta_{i} *\left(R_{m}-R_{f}\right)
$$

$R_{f}=$ Risk-Free Rate

$\beta_{i}=$ Beta of the Investment

$\left(R_{m}-R_{f}\right)=$ Market Risk Premium

The cost of equity for this final project was $23.25 \%$ using the CAPM model, risk-free rate $5.56 \%$ from 5 years government yield bond from the end of December 2021, unlevered beta is 0.87 acquired from Damodaran industry beta of beverages (soft), debt to equity ratio 2.33 , with the tax rate for restaurant and café at $10 \%$, resulting in the levered beta of 2.7 , and risk equity rate premium from Damodaran of $6.56 \%$.

Table 2 WACC Calculation

\begin{tabular}{|l|c|c|c|c|}
\hline WACC Calculation & Weight & Amount (in IDR) & Cost & Weighted Cost \\
\hline \multirow{2}{*}{ Owner's Equity } & $30 \%$ & $72,650,394.60$ & $23.25 \%$ & $6.98 \%$ \\
\hline \multirow{2}{*}{ Debt/Bank Loans } & $70 \%$ & $169,517,587.40$ & $7.43 \%$ & $5.20 \%$ \\
\hline \multirow{2}{*}{} & $242,167,982.00$ & Total & $12.18 \%$ \\
\hline
\end{tabular}

Source: Internal Analysis, 2021

$4 \mid$ 
For the assumption, author and Sekala has decided for some aspect to be reviewed, for revenue projection, the author interviewed the management team of Sekala, and come up with occupancy plan based revenue projection. In this revenue projection, total revenue is measured by estimating the occupancy of Sekala for the next 5 years that later on will be multiplied by the average or assumed spending per customer. The new outlet of Sekala will have a maximum capacity of 70 with an average of 3 times turnover per day, which led to maximum occupancy per day of 210 customers. Sekala also opens up an average of 350 days a year, so with that, the maximum occupancy of Sekala in a year is 73500 . The average spending of Sekala's customers is assumed by the purchase of 1 food and 1 drink with an estimated worth of IDR 50,000.00 that will be increased every year because of the average of $4.23 \%$ inflation. The annual occupancy that the management expecting was $30 \%$ in the first year with the constant growth of 5\% every next year. For raw material is the main production aspect to run Sekala business operations, in Sekala, raw material is defined as inventory, it is required to create a product that will generate sales and revenue for Sekala, as mentioned earlier in the Sekala Projection of inventory for covering the sales will be projected for $42 \%$ of total revenue, it was assumed based from the historical data of Sekala, $1 \%$ from its inventory will be used for research and development and to maintain the business, it was projected to use $40 \%$ from $42 \%$ the inventory. Sekula's new place is owned by Urbane, Sekala agreement with Urbane is by consignment, not with rent payment, the projected consignment percentage is $25 \%$ from Sekala's total revenue. To prevent any unnecessary issues, Sekala set a cash saving policy of $5 \%$ from its revenue, or approximately nearly twice the current cash saving, this is necessarily needed to be kept for any sudden operational or any sudden needs. The main reason for this cash saving is for emergency matters. Marketing is an important aspect for a coffee shop and restaurant industry to reach out to their customers to increase its brand awareness, therefore Sekala prepared $5 \%$ of its total revenue for marketing requirement costs. Maintenance expenses cost has been set by Sekala at 5\% from its current fixed assets, it was required to keep the equipment of Sekala running efficiently to maintain the equipment until the life cycle reached the goals of usage by the company. Operating expenses in Sekala are including electricity, water, and other operational needs, that are needed to keep the business process going. Sekula's current operational cost is running on $61,000,000.00$ per year, and the operating cost for the new outlet was assumed to increase by $30 \%$, with $5 \%$ growth per year. Research and development in Sekala include the use of inventory and consultant cost; this was required to create and maintain a new menu for Sekala to keep innovating in the business.

The result of this study which the rest of assumption criteria are assumed by the owner of Sekala and from their own historical data shows that the project is feasible for Sekala to be executed with all the capital budgeting result are acceptable, The payback period is on 1.22 years and the boundaries that has been set by the Sekala's management and owners are at 3 years or 1 year before the start of the managerial wages will be paid, the projected NPV for this project is on IDR $513,913,208.73$, it is acceptable because the minimum NPV for a project to be accepted is higher than zero (IDR 0.00), it means that this project has successfully overrun it cost to not reach zero or under zero NPV, the B/C Ratio result show that the project has 3.12 ratio which would be accepted because it is higher than 1 , this means that the benefit or cash inflow is higher than the cost or cash outflow which will gives positives outcome, and the internal rate of return which shows $19.72 \%$, with the cost of capital of $52.04 \%$ this means that the project is feasible and acceptable for Sekala to be executed because it was higher than the cost of capital for the project. 
RSF Conference Series: Business, Management and Social Sciences, Vol. 1 (2), 01-09

Investment Project of Sekala: Should Sekala Open Up a New Outlet?

Fario Pranadi Prakoso, Sylviana Maya Damayanti

Table 3 Feasibility Analysis Result

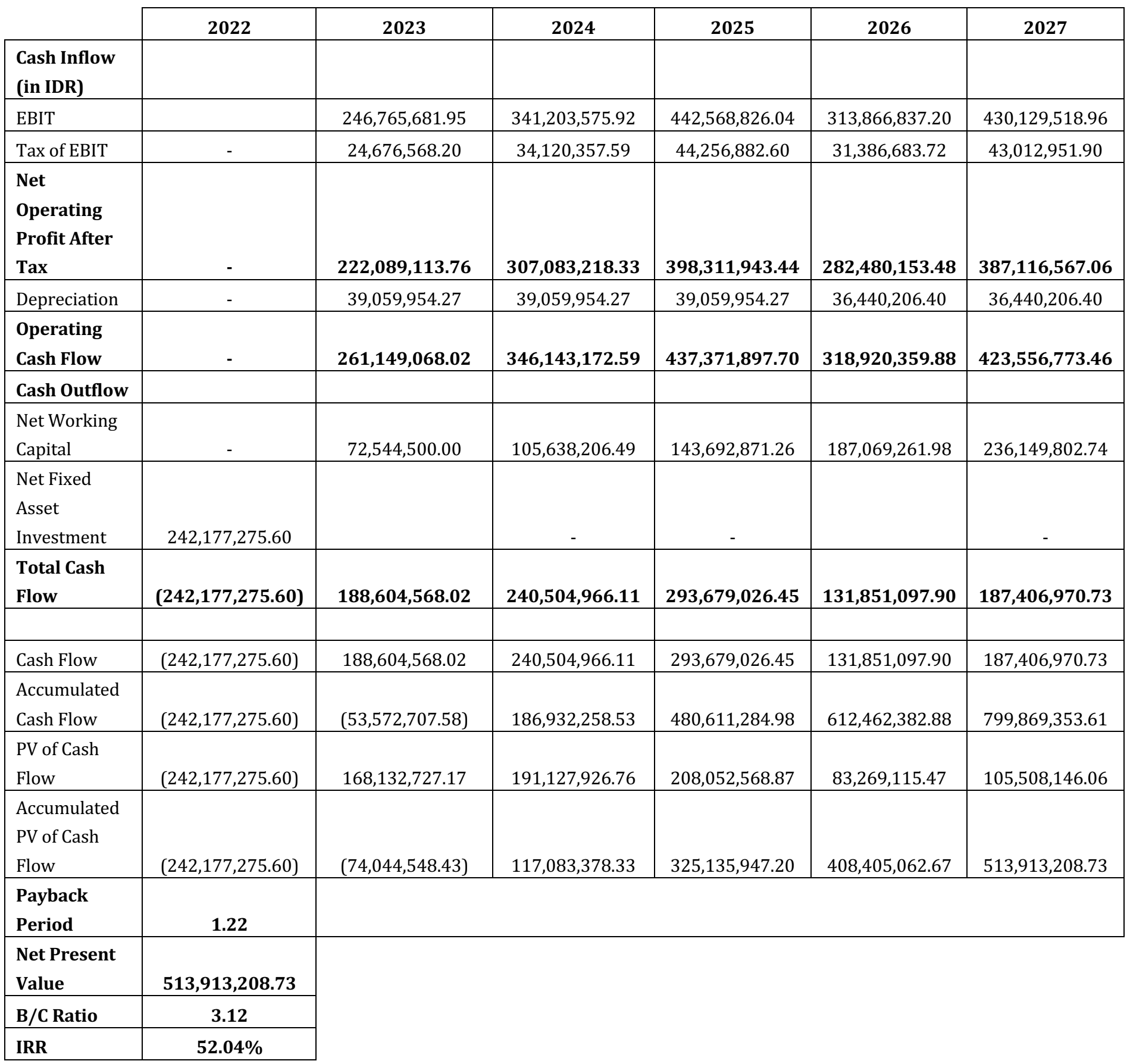

Source: Internal Analysis, 2021

In the sensitivity result author choose the swing of + and $-25 \%$, sensitivity analysis was conducted to see which aspect will have the higher chance of generating zero NPV, as a result, came 
RSF Conference Series: Business, Management and Social Sciences, Vol. 1 (2), XX-XX

Investment Project of Sekala: Should Sekala Open Up a New Outlet?

Fario Pranadi Prakoso, Sylviana Maya Damayanti

out there is four aspects that gives the highest chance as their absolute chance is above $25 \%$, there are, raw materials, selling price, occupancy, and occupancy growth.

Table 4 Sensitivity Result

\begin{tabular}{|l|c|c|}
\hline Sensitivity & Assumption & $\begin{array}{c}\text { Absolute } \\
\text { Change }\end{array}$ \\
\hline Raw Material & $42.00 \%$ & $1815.37 \%$ \\
\hline Selling Price & $50,000.00$ & $500.59 \%$ \\
\hline Occupancy & $30.00 \%$ & $377.29 \%$ \\
\hline Occupancy Growth & $5.00 \%$ & $123.30 \%$ \\
\hline Marketing & $5.00 \%$ & $77.74 \%$ \\
\hline Inflation Rate & $4.23 \%$ & $43.32 \%$ \\
\hline Wages Growth & $10.00 \%$ & $36.40 \%$ \\
\hline Tax Expense & $10.00 \%$ & $26.41 \%$ \\
\hline Operating Expense & $30.00 \%$ & $20.05 \%$ \\
\hline
\end{tabular}

Source: Internal Analysis, 2021

In the Monte Carlo simulation, the simulation runs randomly with the differentiation in the most sensitive aspect that can make the company zero NPV, author run the simulation 500 times, with the result of, the minimal NPV of $(27,703,020,655.98)$, maximal NPV of 49,461,189,415.89, average NPV from 500 simulations of 665,492,768.10 ,standard Deviation of 7,108,905,139.40, median NPV of $134,200,242.94$, kurtosis of 3.76 , the kurtosis is above the normal distribution of kurtosis, which is 3 , this means that the project has higher risk to be executed, skewness of 0.45 , with the normal distribution for skewness is 0 , this result means that the data from the simulation is pushed toward the right side, which means, the average, median, and maximum value are positives, and the probability of giving zero NPV or lower is $46.27 \%$ the percentage constantly changing between $45 \%-55 \%$, this was too risky for Sekala to continue the project because the probability was too high to make the project sustained.

Table 5 Monte Carlo Descriptive Statistics

Descriptive Statistics (in IDR)

\begin{tabular}{|l|c|}
\hline Min & $(26,537,377,141.96)$ \\
\hline Max & $26,638,477,404.13$ \\
\hline Mean & $839,118,134.17$ \\
\hline Standard Deviation & $5,984,975,603.72$ \\
\hline Median & $86,025,988.28$ \\
\hline Kurtosis & 3.15 \\
\hline Skewness & 1.03 \\
\hline Prob NPV<0 & $44.07 \%$ \\
\hline
\end{tabular}

Source: Internal Analysis, 2021 


\section{CONCLUSION}

In the conclusion section author will conduct the final result of the analysis from the research question in chapter 1 based on the analysis from the previous chapter, the conclusions are:

1. The outcome of financial projection for Sekala new outlet

The outcome for the projection of the new outlet for Sekala in 5 years based on the result from chapter 3 is, the NPV outcome is positive on IDR 513,913,208.73, the payback period is on 1.22 years from the target of a maximum of 3 years, the benefit-cost ratio is on 3.12 with the minimum requirement of higher than 1, internal rate of return is on $52.04 \%$, higher than the cost of capital of $12.18 \%$. From the result of all the financial projections, the project is accepted and feasible to be executed by Sekala.

2. Success probability for the project

Based on the feasibility analysis, the success probability for the project is high because all of the outcomes for every aspect of capital budgeting is accepted, but based on the risk analysis and Monte Carlo simulation, the probability of project to success can be assumed as low, because whether the skewness is above 0 , but the kurtosis is above 3 which create a higher risk for the project, also the probability of net present value $<0$ is constantly at $40-55 \%$, and it is risky for Sekala, and with the range gap of NPV from worst to the best case is IDR $15,776,006,857.68$ that was big enough to make the owners of Sekala think again for the news outlet.

Table 6 Risk Scenario Analysis

\begin{tabular}{|l|c|c|c|}
\hline \multicolumn{1}{|c|}{ (in IDR) } & Worst Case & Assumption Case & Best Case \\
\hline & $\mathbf{1}$ & $\mathbf{2}$ & $\mathbf{3}$ \\
\hline Raw Material & & & $28.82 \%$ \\
\hline Selling Price & $167.04 \%$ & $42.00 \%$ & $88,000.00$ \\
\hline Occupancy & $14,000.00$ & $50,000.00$ & $55.34 \%$ \\
\hline Occupancy Growth & $8.21 \%$ & $30.00 \%$ & $20.39 \%$ \\
\hline & $1.11 \%$ & $5.00 \%$ & \\
\hline NPV & & & $13,380,292,890.41$ \\
\hline & $(2,395,713,967.26)$ & $513,913,208.73$ & \\
\hline
\end{tabular}

Source: Internal Analysis, 2021

\section{REFERENCES}

Agnes Cheng, C., \& Newman, M. (2014). Capital Budgeting. Wiley Encyclopedia of Management. Ashley, R., Atkinson, S., \& LeBruto, S. (2013). A Survey of Capital Budgeting Methods Used by the Restaurant Industry. The Journal of Hospitality Financial Management, 46-55.

Grant, T. (2020, November 11). How Covid-19 Changed Home Coffee Consumption. Perfect Daily Grind: https://perfectdailygrind.com/2020/11/how-covid-19-changed-home-coffeeconsumption/ 
RSF Conference Series: Business, Management and Social Sciences, Vol. 1 (2), XX-XX

Investment Project of Sekala: Should Sekala Open Up a New Outlet?

Hall, J. (2000). Investigating Aspects of the Capital Budgeting Process Used in the Evaluation of Investment Projects. South African Journal of Economic and Management Sciences.

Healthline. (2018, September 28). The Effects of Caffeine on Your Body. Healthline: https://www.healthline.com/health/caffeine-effects-on-body

Siziba, S. (2019). The Evolution of the Application of Capital Budgeting Techniques in Enterprises. Global Finance Journal. 